Article

\title{
Internet of Energy (IoE) and High-Renewables Electricity System Market Design
}

\author{
Wadim Strielkowski ${ }^{1, *}$, Dalia Streimikiene ${ }^{2} \mathbb{D}$, Alena Fomina ${ }^{3}$ and Elena Semenova ${ }^{4}$ \\ 1 Department of Trade and Finance, Faculty of Economics and Management, Czech University of Life Sciences \\ Prague, 16500 Praha-Suchdol, Prague, Czech Republic \\ 2 Lithuanian Energy Institute, Breslaujos 3, LT-44403 Kaunas, Lithuania; dalia@mail.lei.lt \\ 3 JSC - Central Research Institute of Economy Management and Information Systems "Electronics", \\ Kosmonavta Volkova str. 12, 127299 Moscow, Russia; fomina@ymservices.ru \\ 4 Department of Innovation and Integrated Quality Systems, Saint-Petersburg State University of Aerospace \\ Instrumentation, Bolshaya Morskaia str. 67, 190000 Saint Petersburg, Russia; eg.semenova@mail.ru \\ * Correspondence: strielkowski@pef.czu.cz
}

Received: 13 November 2019; Accepted: 15 December 2019; Published: 16 December 2019

\begin{abstract}
The growing importance of the Internet of Energy (IoE) brands the high-renewables electricity system a realistic scenario for the future electricity system market design. In general, the whole gist behind the IoE is developed upon a somewhat broader idea encompassing the so-called "Internet of Things" (IoT), which envisioned a plethora of household appliances, utensils, clothing, smart trackers, smart meters, and vehicles furnished with tiny devices. These devices would record all possible data from all those objects in real time and allow for a two-way exchange of information that makes it possible to optimize their use. IoT employs the Internet Protocol (IP) and the worldwide web (WWW) network for transferring information and data through various types of networks and gateways as well as sensor technologies. This paper presents an outline stemming from the implications of the high-renewables electric system that would employ the Internet of Energy (IoE). In doing so, it focuses on the implications that IoE brings into the high-renewables electricity market inhabited by smart homes, smart meters, electric vehicles, solar panels, and wind turbines, such as the peer-to-peer (P2P) energy exchange between prosumers, optimization of location of charging stations for electric vehicles (EVs), or the information and energy exchange in the smart grids. We show that such issues as compatibility, connection speed, and most notoriously, trust in IoE applications among households and consumers would play a decisive role in the transition to the high-renewables electricity systems of the 21st century. Our findings demonstrate that the decentralized approach to energy system effective control and operation that is offered by IoE is highly likely to become ubiquitous as early as 2030. Since it may be optimal that large-scale rollouts start in the early 2020s, some form of government incentives and funding (e.g. subsidies for installing wind turbines or solar panels or special feed-in-tariffs for buying renewable energy) may be needed for the energy market to make early progress in embracing more renewables and in reducing the costs of later investments. In addition, there might be some other alternative approaches aimed at facilitating this development. We show that the objective is to minimize the overall system cost, which consists of the system investment cost and the system operating cost, subject to $\mathrm{CO} 2$ emissions constraints and the operating constraints of generation units, network assets, and novel carbon-free technologies, which is quite cumbersome given the trend in consumption and the planned obsolescence. This can be done through increasing energy efficiency, developing demand side management strategies, and improving matching between supply and demand side, just to name a few possibilities.
\end{abstract}

Keywords: renewable energy sources; sustainability; Internet of Energy; smart meters; smart grid 


\section{Introduction}

Smart grid technologies would make it possible to be more efficient in terms of using energy sources and optimizing them, whenever necessary, with regard to the environmental or power system limitations. With all that, various energy strategies can be implemented for creating benefits for all system users and for providing them with clean and cheap energy at all times. As renewable energies mature, prices fall, education improves, and competitiveness improves, the likelihood of technology spreading across national borders increases.

Given the current state of technological development and the energy market, it is likely that the high-renewables electricity system market design of the future would be based on smart grids powered by the Internet of Energy (IoE) [1]. The term "smart grid" is characteristically used for describing an electricity system that supports four basic operations encompassing electricity generation, electricity transmission, electricity distribution, and electricity control [2-4]. A smart grid is based on the bidirectional exchange of information and energy within the electricity networks. Using its unique qualities, it is capable of optimizing, saving, and delivering energy precisely where it is needed [5].

Smart grids of the future would involve large shares of renewable energy sources (RES). Generating electricity from renewable energy sources would provide direct and indirect economic benefits beyond cost, as well as environmental benefits from reducing $\mathrm{CO}_{2}$ emissions. Moreover, generation of electricity from renewable energy sources integrated into the smart grid system can be one of the best options for future energy security. The smart grid system addresses the deterioration of the power source and the modern information technology for communication and improves the efficiency of power distribution.

However, this renewable energy is likely to be generated not only at the industry level (e.g., by large state or private companies) but also at the household or individual level. In the future, every energy consumer would become a "prosumer" (an agent at the electric energy market that is simultaneously buying, producing, and often selling electric energy) as described, for example, by Mengelkamp et al. [6]. Thence, it would be very important to link all pro-active prosumers as well as large energy producers and users into efficient networks that would allow a two-way flow of information and energy [7]. To meet future energy needs, the smart grid system can be used as an efficient energy security system. Nevertheless, this cannot be achieved without the profound use of information and communication technologies (ICTs).

Here is where the Internet of Energy (IoE) comes in being the fastest in all current energy transfers because the actual speed as well as the efficiency of the energy transfer [8]. Even though IoE might seem like a very novel idea, it is largely based on the advancements, rules and the general architecture of the "old-fashioned" information and communication technologies (ICTs) and Internet. Putting things very simply, IoE consists of millions of energy-generating installations, as well as devices and household appliances that report back to the power grid using peer-to-peer or server-based network for receiving information, running an analysis, and sending commands [9-11]. Thence, in the nearest future, high-renewables smart grids would enable the two-way flow of information and energy with a purpose of providing power for all system users [12,13].

With regard to the above, for achieving the high-renewables electricity system market design it would be crucial to move to the rapid energy transfer and planning in the future. Renewable energy sources are being introduced in an unequal environment where their energy prices do not fully reflect the externalities. The global subsidies for traditional fuels and nuclear energy remain high despite the benefits of renewable energy and concerns about environmental quality. Much of the expansion of renewable capacity occurs in countries with large subsidy systems that can compensate investors for the relatively high cost of renewable energy technologies.

Many aspects, such as electromagnetics, materials science, information science, automation, and the like are involved in the generation, conversion, transmission, distribution and power consumption of the smart grids. Therefore, it requires a lot of talent to work together or to accompany [14,15]. With the breakthrough of materials science and power electronics, the advantage of some advanced technologies that would further boost the smart grids and high-renewables systems such as direct current (DC) 
transmission is obvious. It is highly likely that DC transmission would become the most important type of energy transfer in the future. In the last ten years or so, several product categories more than doubled, including home-based energy management systems, smart lighting controls, residential demand response, and building information modelling, as pointed out by Luca de Tena et al. [16]. Led by solar, wind and gas turbines, this segment represents more than a quarter of the advanced and RES-focused energy market.

High-renewables electric smart grids of the future powered by the IoE would largely benefit from the optimal solutions applied to smart homes, electric vehicles (EVs), solar panels, wind turbines, as well as peer-to-peer (P2P) flow of electricity and information between prosumers. Nevertheless, the transition to the high-renewables electricity systems of the $21^{\text {st }}$ century would have to tackle many technical issues such as compatibility, connection speed, as well as social acceptance.

This paper is structured as follows: Section 2 provides a thorough literature review focusing on the innovative policies for promoting high-renewables smart electricity systems and smart grids. Section 3 describes smart network technologies. Section 4 provides scenarios for the high-renewables electricity system market design that would employ IoE. Finally, Section 5 concludes with outlaying some final outcomes and policy implications.

\section{Literature Review}

IoE represents a global interconnected network that is comprised of various household and industrial appliances, electric devices, large and small, as well as smart grids that interconnect them all together. Another important element of IoE is, of course, the presence of smart meters, or sensors that constantly monitor all processes within this network and send signals across the grid, helping the IoE to understand the appliances schedule and the consumers to adjust their energy consumption patterns and usage. [17-19]. All in all, it becomes quite apparent that IoE is capable of helping in achieving and further increasing the sustainability for the smart grids through making the production, transmission, and consumption of electric energy more efficient and economically feasible. With all that benefits smart grids and IoE are offering, it is quite surprising that many agents at the contemporary energy market (e.g., car producers, energy suppliers, or utility companies), still have certain troubles in adjusting to the new technological advancements [20,21] (even though it is apparent that their deployment requires substantial capital investments). However, it quite clear that new types of energy demand and supply that would include more renewable energy sources and prosumers would inevitably lead to the profound changes in world's electrical networks. With regard to that, smart grids offer a whole scale of opportunities how to tackle these changes depending on the concrete situation, business models, regulation, and power infrastructure [22,23].

Figure 1 that follows, shows how the flexibility and innovations trends in IoE framework and its applications to high renewables penetrations of electricity market are driving energy transition. There are three main aspects to be considered that mark the transformation of the sector (digitalisation, decentralisation, and electrification).

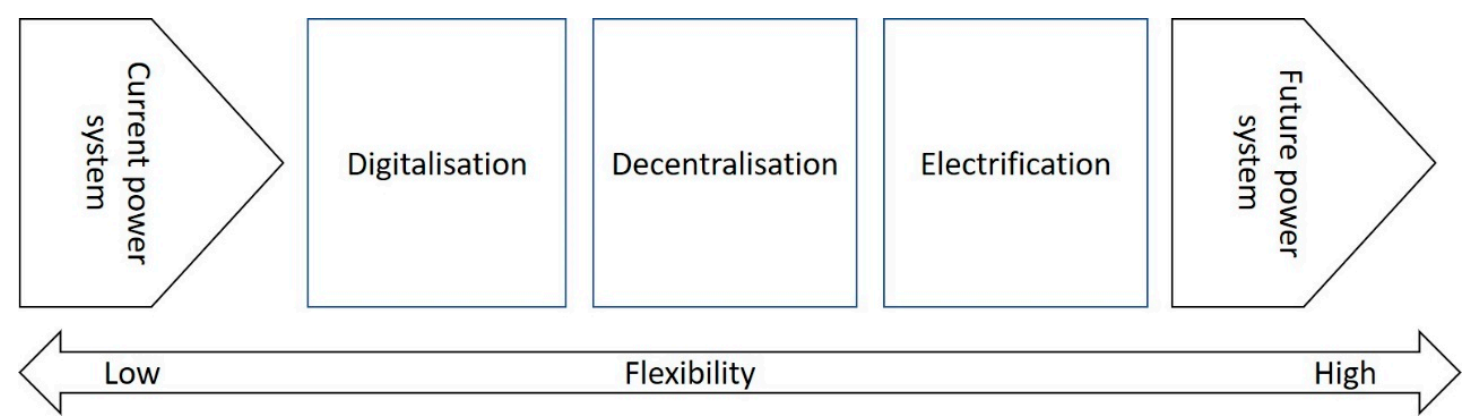

Figure 1. Flexibility and innovations in the Internet of Energy (IoE) and high renewables framework. Source: Own results. 
With regard to the above, one can see how the aspects outlined above impact the transition to the high renewables penetrations of electricity market: digitalisation includes ICT solutions to exchanging data and energy in the framework of IoE, decentralisation embeds the distributed energy resources (DERs) that would help to further decentralise the future power system, while electrification means the increasing share of electric transport, industry, and buildings.

Furthermore, high penetration of renewables also makes the IoE an indispensable tool for the dynamic demand response, when the utilities need to reschedule or delay the operation of the appliances located in households and businesses during the periods when demand levels spike. This is particularly useful due to the intermittent nature of RES.

In the future, high-renewables electricity system market design would encompass the new concepts of energy consumers' and producers' relationships, market operations, as well as electric energy trading [24-27]. IoE and the smart grid would allow for the two-way flow of information and energy in the real time as we know it from the world wide web (WWW) and the Internet [28]. There would be many interesting and useful applications that might be helpful in mitigating power system operation hurdles and natural challenges. For example, Pina et al. [29] analyze the impact of demand side management strategies in the evolution of the electricity mix of Flores Island in the Azores and conclude that IT solutions might improve the operation of the existing installed capacity. Moreover, Strielkowski et al. [30] explain in greater detail how photovoltaic system owners can control their use of electricity using the "power manager" gateways and battery storage for achieving the economically effective outcome. Another interesting case study involving the IoE and its implications for the smart grids is the autonomic power system (APS), that presents a novel concept of "self"" (self-configuring, self-healing, self-optimizing, and self-protecting) system [31]. APS constituted a system-wide approach with the decentralized intelligence making autonomous decisions required for meeting the priorities of the system's stakeholders, employing the integration of a vast number of flexible, diverse, and independently controlled technologies in system operation and planning [4,32,33].

When it comes to the technical details and characteristics for the IoE applied to the electricity market in terms of high variable renewable resources penetration, various layers of IoE in smart grids covering management services (security control, data monitoring, customer or market data) and applications (smart homes, electric vehicles, demand response, and demand side management) can be considered: e.g., transport layer, physical layer, network layer, or application layer [34,35].

IoE and smart grids would allow system operators to promptly react to peaks or failures in electric energy demand and also to forecast these issues well in advance and to adjust to these situations by optimizing energy generation from, say, RES, accordingly. All these would increase energy market efficiency and profitability [36-39]. In a way, it is quite similar to the so-called "cashless economy", when the Internet is used to optimize payments and money transfers, and banks, financial institutions, as well as government regulators have an instant snapshot of all of those activities and transactions.

Energy companies operating on the future high-renewables and smart solutions-driven electricity market would be involved into the generation of energy from renewable sources and natural gas, energy trading and tailor-made energy services and developments for companies [40,41]. They would offer their customers a reliable and environmentally friendly energy supply based on the sustainable use of renewable energies.

Another important aspect is smart meters. Their numbers are increasing, and their usage is becoming notorious in all aspects of energy generation and saving. However, in some cases, as for example, Rausser et al. [42] demonstrate using a case study from the Republic of Ireland, their deployment has little effect of the energy consumption behaviour of the households and individuals. Nevertheless, smart meters would also be a very important pillar of the high-renewables sustainable energy system [43,44]. In the future market design, the peak load shave would be achieved by shifting the usage time of the energy without changing the total energy consumption [45]. It works on the application of smart meters to collect data and optimize energy production [46]. Although this strategy improves the conventional grid, the IoE framework is not considered a mathematical model 
and the inclusion of renewable energy sources is lacking. The introduction of smart meters and IoE connected power supplies has allowed consumers to track and monitor their energy consumption and save energy costs. This has many practical applications and technical solutions, in particular in Smart Cities that represent a communication infrastructure offering a concise, unified and affordable access to municipal services including energy supply [47].

Similar technology is expected to make aggressive progress in the areas of energy production and transmission $[48,49]$. This massive and rapid growth is aimed at efficient use of resources in power generation and higher operational efficiency to meet growing energy needs [50-52].

With limited participation of demand resources, the wholesale market functioned mainly with network operators selling large central station equipment to meet the steady demand. Renewable energy today is cheaper than coal and nuclear power in most parts of such advanced economies as, for example, the United States and more cost-competitive with natural gas [53,54].

Furthermore, it becomes obvious that the targeted rapid increase in power supply from intermittent renewable sources in many countries is a fundamental challenge to the smooth functioning of many power systems. Wind and solar power are the fastest growing forms of renewable energy $[55,56]$. The supply of wind and solar energy is largely determined by wind speed and solar radiation which can be correlated only slightly with the times of electricity demand [57-59]. It is this feature of renewable energy intermittent power supply that adds cost to the entire generation system that is implicitly paid for by either other producers, consumers or taxpayers [60,61]. With the constantly increasing size and quantity, today's generation and energy costs are often competitive with coal and nuclear without taking into account the reserve capacity and complexity of grid connectivity that affect their value in a system [62]. If it burns out and displaces electricity from other sources, it can reduce the profitability of these sources and increase supply prices. It has been proposed to use all electricity from wind and solar power which greatly simplifies the management of the electricity grid [63,64].

Effective wholesale electricity markets are crucial for rapid and affordable decarbonization, as they demonstrably invest efficiently and rapidly in new technologies. However, the electricity markets will only support massive investments in clean energy if they are able to send efficient price signals as decarbonization increases $[65,66]$. The scale and pace of investment required to halt the climate crisis means that wind and solar energy will almost certainly play an important role in future power systems because of their low cost and speed of deployment. However, variable power and the marginal cost of wind, solar and other forms of variable renewable energy (VRE) jeopardize the ability of current market designs to send the required price signals $[67,68]$. New variable resources such as sun and wind are one of the biggest drivers for more flexibility. There are many ways to unlock flexibility: new and more flexible gas systems, storage of all sizes, power electronics to regulate wind and solar power, and a constellation of connected devices ready to consume electricity smarter. Restructuring wholesale electricity markets, which work best by avoiding specific technology revenues, must find new and improved ways to assess flexibility and allow current and future market participants to provide them at minimal cost. The uneven geographic distribution of wind and solar potential is likely to burden the grid at some sites, resulting in transmission and distribution restrictions. Some electricity markets, such as the California Independent System Operator (CAISO) in Germany and the United Kingdom, have begun to recognize variable and resilient electrical resources to varying degrees [69,70]. In addition, the Federal Energy Regulatory Commission (FERC) and Pennsylvania-New Jersey-Maryland (PJM) Interconnection policy makers in the United States are also shifting their focus to the role that battery energy storage and flexible resources such as distributed resource aggregators (DRAs) play in the development of electricity markets [71]. However, regulatory, economic and technological barriers have largely prevented the participation of demand resources such as batteries and smart thermostats in the wholesale electricity market. With limited participation of demand resources, the wholesale energy market functioned mainly with network operators selling large central station equipment to meet the steady demand. 


\section{Promoting High-Renewables Smart Grids}

High-renewables smart grids would bring in many useful solutions to the existing energy market problems. Flexible demand, micro-generation and energy storage technologies can reduce the emerging demand peaks, while smart network technologies increase the utilization of existing network assets. The concept represents a shift from asset redundancy to more intelligent operation through real-time coordination of new flexible technologies. Figure 2 that follows offers the comparison of the costs of electricity obtained from the renewable energy sources.

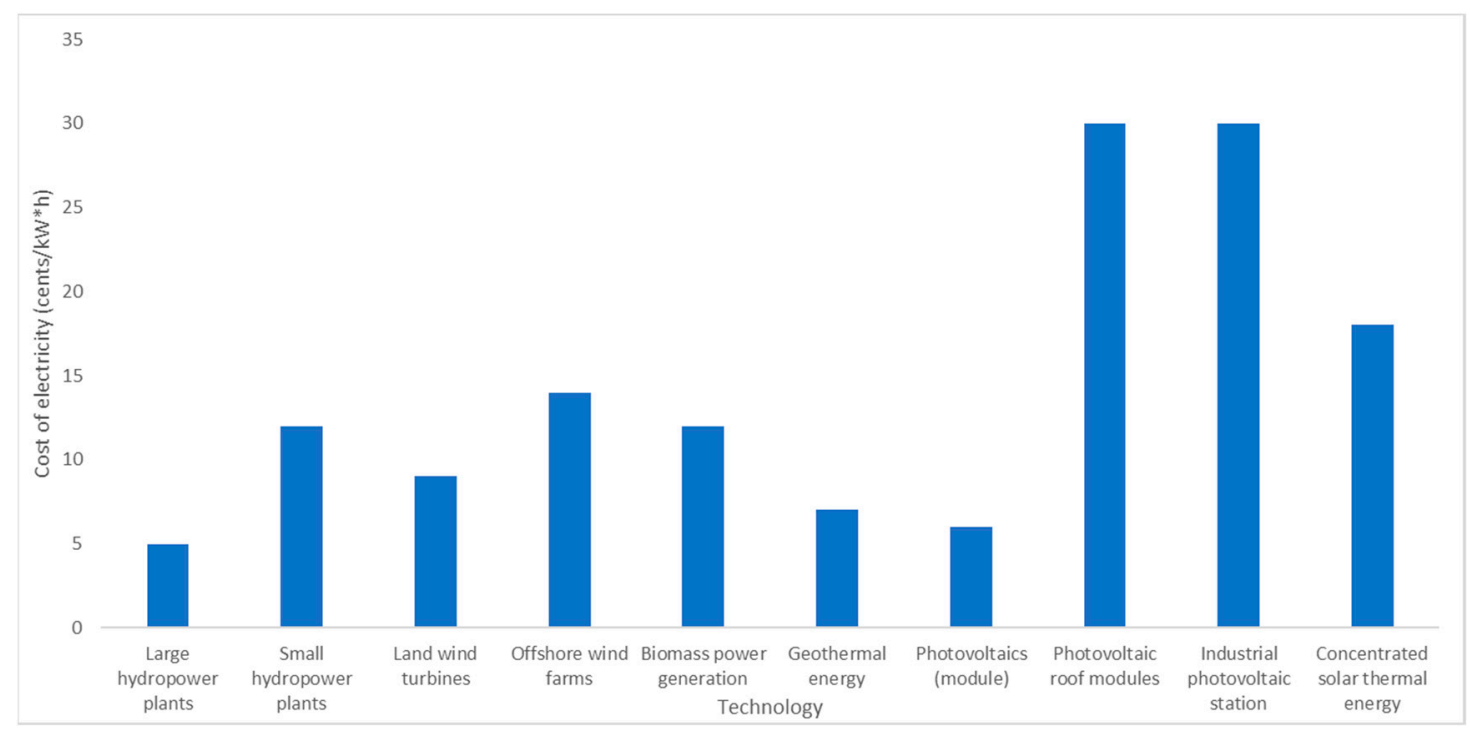

Figure 2. Comparison of the costs of electricity obtained from the renewable energy sources. Source: [72].

Overall, it becomes obvious that in spite of the popularity of RES-based technologies, the costs of electricity are the lowest when it comes from the large hydropower plants, which is followed by the geothermal energy and biomass. Photovoltaics and wind turbines are just starting to catch up in terms of economic efficiency.

In general, it would be quite straightforward to simultaneously and holistically assess the impact of high-renewables smart grid technologies across all timescales and system levels via capturing the overall economic value of these technologies for three milestone dates (2020, 2030, and 2050). In the current situation (2020) the value of flexibility is not that high, the deployment of energy storage is not justified for a cost higher than $€ 1100 / \mathrm{kW}$ with the optimal storage capacity of $2 \mathrm{GW}$, and its overall economic value for the power system for the European country a size of the United Kingdom or Germany being around $€ 0.5$ billion per year.

There have been recent developments-in the UK with electricity market reform, in Germany with the Energiewende, and in the State of New York with its Reforming the Energy Vision-for ideas from the new round of natural experiments in electricity market organization, currently underway in jurisdictions with $80 \%$ or more low carbon electricity targets.

A fundamental feature of the high-renewables electricity system market design's vision is the integration of a vast number of flexible, diverse, and independently controlled technologies in system operation and planning. Figure 3 that follows depicts the investments into smart grids by areas. It is apparent that over the past few years the share of investments into the rest of the network is declining, while the investments into the power equipment as well as to the smart grid infrastructure and smart meters are slowly but steadily increasing.

Table 1 that follows shows the contrasting description of two market designs-namely the Internet of Energy and high-renewables market design versus the current (state-of-the-art) design that employs current technological advancements. 


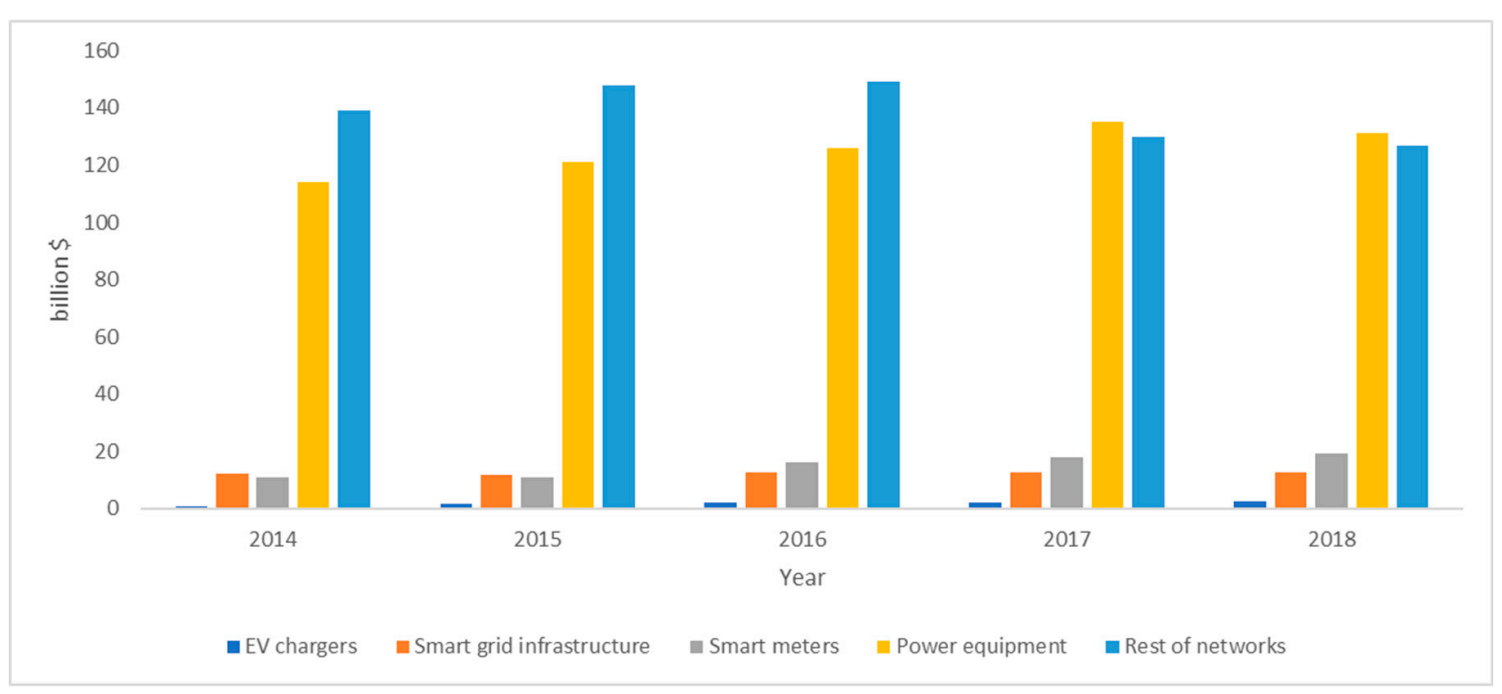

Figure 3. Investments into smart grids by areas. Source: [73].

Table 1. IoE and high-renewables market design versus current state-of-the-art.

\begin{tabular}{|c|c|c|}
\hline Major Issues & Positive Attributes & Negative Attributes \\
\hline \multirow{4}{*}{ Flexible technologies } & Flexible generation & Inflexible generation \\
\hline & $\begin{array}{l}\text { Interconnection and flexible network } \\
\text { technologies }\end{array}$ & $\begin{array}{l}\text { Isolated and conventional generation } \\
\text { technologies }\end{array}$ \\
\hline & Demand side response & Traditional distribution and consumption \\
\hline & Energy storage & Obsolete energy storage \\
\hline \multirow{4}{*}{ Market operation } & Improving system control & Inefficient and obsolete system control \\
\hline & Big Data & "Old-style" approach to Big Data \\
\hline & Integration of transmission and distribution & Isolated transmission and distribution \\
\hline & Decentralized control & Centralized control \\
\hline \multirow{5}{*}{ Market design } & Revisiting the current design principles & Existing design principle \\
\hline & Moving beyond "like-for-like" replacements & Like-for-like replacements \\
\hline & Strategic investments & No strategic investment or planning \\
\hline & Managing uncertainty & Old-fashioned traditionalist approach \\
\hline & Improving resilience of high impact events & Vulnerability of high impact events \\
\hline \multirow{3}{*}{$\begin{array}{l}\text { Coordination and } \\
\text { implementation }\end{array}$} & Transmission coordination & No harmonization of regimes \\
\hline & Whole systems approach & Fragmented system approach \\
\hline & Coordination across energy vectors & Single-energy system planning \\
\hline \multirow{7}{*}{$\begin{array}{l}\text { Novel commercial } \\
\text { and regulatory outline }\end{array}$} & Altering the regulator's role & Traditional regulator's role \\
\hline & Providing incentives for the smart grid & Asset-based regulatory philosophy \\
\hline & Setting level playing field markets & No level playing field markets \\
\hline & $\begin{array}{l}\text { Merging the wholesale and retail markets } \\
\text { and cost-reflective charging }\end{array}$ & $\begin{array}{l}\text { No integration of wholesale and retail } \\
\text { markets }\end{array}$ \\
\hline & Altering the role of system operators & $\begin{array}{l}\text { Traditional roles of independent system } \\
\text { operators (ISO) and distribution system } \\
\text { operators (DSO) }\end{array}$ \\
\hline & $\begin{array}{l}\text { Acknowledging the higher risk of smart } \\
\text { technologies }\end{array}$ & $\begin{array}{l}\text { No recognition of risk from new } \\
\text { technologies }\end{array}$ \\
\hline & Deepening the EU integration & Split-up of the EU \\
\hline
\end{tabular}


With regard to the above, it appears important to consider how one can better balance supply and demand, aiming towards an electricity market where prices are reflective of costs to the overall system. For example, in the United Kingdom alone, smart power could save consumers up to $£ 8$ billion a year by 2030 [75]. Moreover, it can also ensure that the UK meets its 2050 carbon targets and secures its energy supply for generations to come. As a result, three major innovations can be identified as the key drivers of success: interconnection, storage, and demand flexibility [76].

Another issue that has to be mentioned in connection with promoting and sustaining high-renewables smart grids is the Big Data which can be used for many activities and innovations within the IoE framework design. In the energy markets, Big Data represents a valuable asset and a source of all possible information about the consumption and behaviour of users, households, and companies [77]. Thanks to the smart meters, Internet and fast mobile technologies, all that information can be collected and transferred quickly to be analysed. However, one has to realize that due to the extensive sizes of such datafiles, traditional methods (e.g., econometric or statistical analysis) are no longer applicable. Instead, computer algorithms and artificial intelligence (AI) are employed which is similar to the recent developments in the "regular" Internet nowadays.

The applications of the Big Data might range from building more accurate predictions and extrapolations that would forecast demand and output more precisely to minimizing asset failures of the system. There is a need for system operators (SO) to become data led organizations (as distinct from asset availability managers) which constitutes an important argument in the debate of the value of independent system operators.

IoE and Big Data are also crucial for energy prosumers that are more entangled into peer-to-peer (P2P) energy market arrangements through buying, selling, and producing their own energy from the renewables. The sharing economy-type of high-renewables energy market that is being created and would be likely to dominate in many countries in the nearest future calls for optimized and fast collection and processing of all available data.

\section{Smart Network Technologies}

With all of the above explained, one also has to point out some noteworthy differences between the smart grids and the Internet, to which they are often compared to. Similar to the Internet (although with a wider diversity of resources), smart grids constitute an interconnected system of devices and controls, nevertheless, all these systems are dynamically evolving and changing as the demand of electricity of the different types of consumers is shifting due to the changing market conditions. The blockchain technology that is used in Bitcoin, the world's most popular cryptocurrency, might provide help in dealing with this highly sophisticated environment for achieving cost-effective energy solutions.

One good example of this is the optimization systems that involve office and residential buildings and electric vehicles (EVs). Managers of these buildings face the tasks of providing a logistically balanced system of charging stations for the EVs parked or stationed on their premises. Another technical solution associated with EVs is the possibility of some of them not only to absorb but also to inject power back to the grid (a so-called "vehicle-to-grid" concept, or V2G). Without smart grids and IoE, it would be quite cumbersome to come up with the optimal mix of accurate solutions due to supply and demand uncertainties: e.g., inherent uncertainty of RES or load shifting for reducing peak power consumption [78,79].

Thanks to IoE smart grids can achieve better efficiency and learn how to optimize the energy needs for both prosumers operating at peer-to-peer (P2P) markets and industrial companies in the production chain. All of that gives a boost for the new sectors such as the solar photovoltaics, intelligent distribution networks, and electric vehicles charging, just to give a few examples. In addition, the rising competition and technological advancements are slowly but gradually changing the current system of distribution networks and old-fashioned grids.

At the planning timescale, flexible demand, micro-generation, and energy storage technologies can reduce the emerging demand peaks, while smart network technologies increase the utilization of 
existing network assets; both these effects are translated in reduced requirements for capital-intensive generation and network capacity investments in the future [80]. Moreover, dynamic demand response shifts the amount of consumer electricity it to when it more optimal from the grid operation point of view [81].

The shift towards carbon-free transport which aims at reducing car emissions and electrify both personal and communal transportation introduced the concept of electric vehicles (EV). Currently, EVs are becoming quite a mundane thing even though their costs and operation might be somewhat higher than in the case of traditional vehicles. Comparing the number of EVs and internal combustion engine (ICE) vehicles, one can find out that in 2019 there were about 5.6 million EVs all around the world (including passenger cars and light commercial vehicles with battery-electric drive, range extender, as well as plug-in hybrids) [82]. This is a steady increase from the 3.2 million EVs in 2018, 1.9 million in 2017, and 1.1 million in 2016 [83]. However, EVs still constitute only a margin of all registered internal ICE vehicles in the world which yielded around 1.4 billion in 2019 [84]. Nevertheless, IoE is becoming one of the key concepts in the electrification of transport, since it promises to coordinate, manage, and match the growing fleet of electric vehicles. For example, one of the pressing issues with EVs today is the occurrence of the charging stations. Nowadays, there are about 160 thousand charging stations worldwide with the expected number to be slightly above 200 thousand in the early $2020[85,86]$ Not too frequent in comparison with their fuel counterparts, they often make it difficult to plan a trip over large distances. One of the solutions might be charging EVs from one another in an interconnected network of drivers who are also energy prosumers (the V2G concept described above). Figure 4 that follows shows a graphic representation of V2G within IoE framework marked by the high renewables penetrations of electricity market. It outlines the key role of the IoE that helps the transition of the power sector through the monitoring the performance of its assets, maintaining more precise operations and control in real time, setting up novel market designs, as well as defining new business models and solutions.

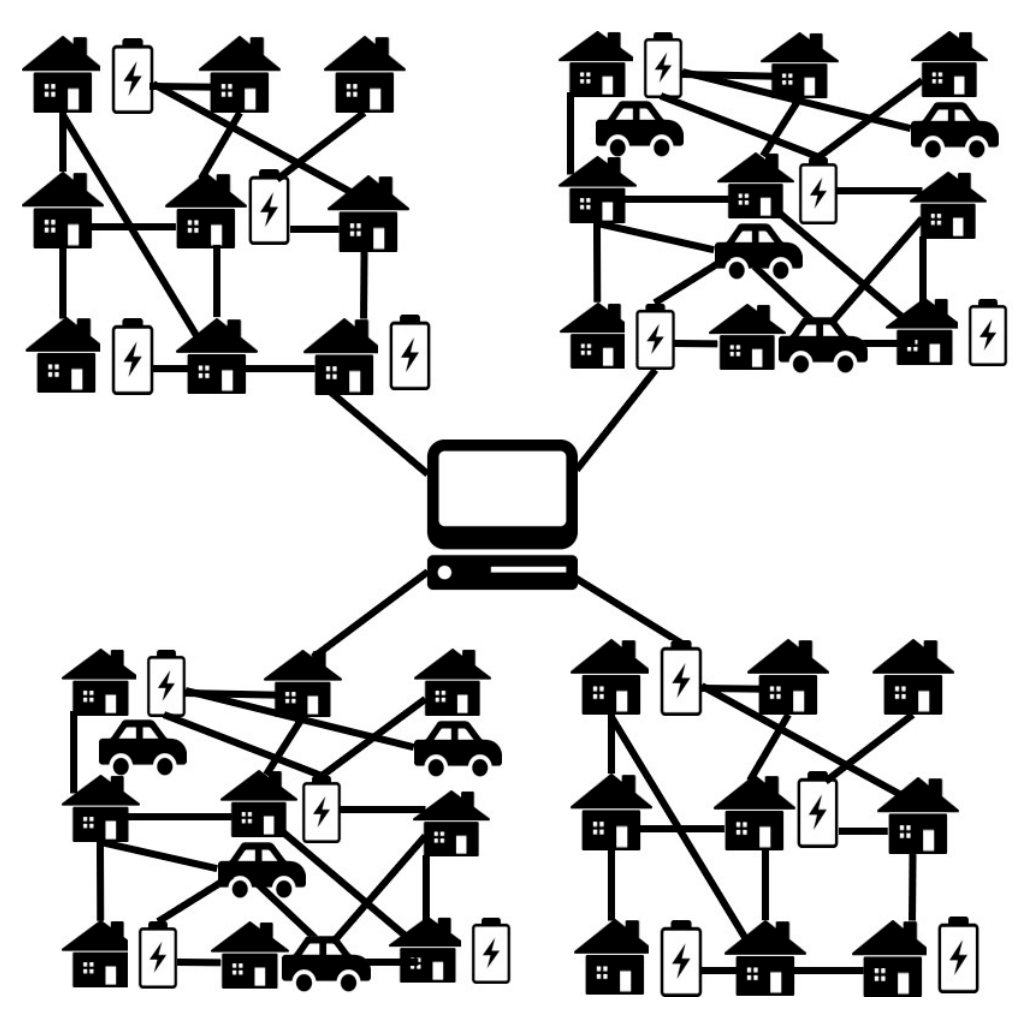

Figure 4. Vehicle-to-grid (V2G) within IoE framework and high renewables penetrations of electricity market. Source: Own results. 
One of the pioneers in introducing the electric transportation to the daily lives of the people is the European Union that committed to having over 250 million EVs by 2025 all across its Member States, which, although an impressive figure in itself, might not even be enough for the effective transition to the climate targets of 2030 [87].

One can see that due to the existing economic and social constraints, electric vehicles might also constitute a problem and distort the power system. They are still too expensive for the average citizen to buy and operate, the charging options are rather limited, and the battery storage is quite modest with the driving range being in a couple of hundreds of kilometres. Thence, technical operation and market optimization need to be used in order for them to become a ubiquitous part of the future smart grids [88].

With the increasing sales of EVs in United States, European Union, China, and India, the vehicle charging issues would accumulate and would need to be solved [89]. For example, in the absence of proper regulations, the majority EV owners would charge their vehicles during the day's peaks, thus placing a burden on the electricity system [90]. IoE might provide solutions for that offering demand-side response and optimizing the charging times scheduling and planning. In addition, the rising EV fleet might become a kind of a giant energy storage system that would be able not only accumulate, but also to move large amounts of energy over distance. This might be an interesting solution for the distributed renewable energy generation, even though strict and precise on-time planning is needed, which should involve Big Data, smart meters of the latest generations, as well as faster mobile networks.

Let us show this on a practical example using the data from the United Kingdom (UK). Table 2 that follows shows an example of tariffs and metered import for the three selected UK regions represented by the Northeast, Central Scotland, and East Midlands (chosen for the best geographical spread and representativeness).

Table 2. Tariffs, distribution charges, and metered import in three selected UK regions.

\begin{tabular}{ccccc}
\hline Region & $\mathbf{F}, \boldsymbol{V}$ & $\mathbf{v}, \boldsymbol{E}$ & $\begin{array}{c}\text { Number of } \\
\text { Customers }\end{array}$ & $\begin{array}{c}\text { Metered Import, } \\
\mathbf{k W h}\end{array}$ \\
\hline Northeast & 0.0483 & 0.027 & $1,500,000$ & 3400 \\
\hline Central Scotland & 0.0373 & 0.04114 & $2,200,000$ & 3800 \\
\hline East Midlands & 0.0147 & 0.02266 & $2,400,000$ & 3900 \\
\hline & & Source: Own calculations based on [30].
\end{tabular}

Furthermore, one might model the hypothetical household demand profile (expressed in GW) with various levels of deployment of electric vehicles (EV)—from $0 \%$ to $100 \%$. This is a rather simplified model since it neglects some relevant benefits of the restructuring market, since more factors might be needed, as well as the relationship between EV and charging stations. Some of the influential factors in this case might be represented by the location of the charging facility, local subsidiary policies, as well as the battery level of the EV. However, despite this limitation, we can draw the model framework that would constitute an example of reorganizing the energy market.

The model in question is based on our methodology described in our earlier paper (for more details see [87]).

$$
(1+x) F+(1+x) v^{*}(E C \times n)=T R
$$

where:

$\mathrm{x}$ - energy tariffs and charges component;

$\mathrm{F}$-household daily unit power fee $(\mathrm{kW})$;

$\mathrm{V}$ - energy unit fee $(\mathrm{kWh})$ for a given household connected to the network;

EC-energy consumption for a given household; 
$\mathrm{N}$-number of households in the system;

TR-total electricity revenues;

Table 3 that follows shows the differences in tariffs (per household per year) for residential EV and non-EV households in the three UK regions presented above. It becomes apparent that the inclusion of RES (represented here by solar panels) and most importantly EVs shift the balance and make profound changes to the economic situation.

Table 3. Differences for residential solar photovoltaic (PV), non-PV, electric vehicle (EV) and non-EV households in UK regions.

\begin{tabular}{|c|c|c|c|c|}
\hline \multirow{3}{*}{$(\mathrm{PV}, \mathrm{EV}), \%$} & \multicolumn{4}{|c|}{ Northeast } \\
\hline & \multicolumn{4}{|c|}{ Tariff, $£$ (per household per year) } \\
\hline & (no EV, no PV) & $(\mathrm{EV}$, no PV) & (no EV, PV) & $(\mathrm{EV}, \mathrm{PV})$ \\
\hline$(1,1)$ & 179.19 & 282.02 & 103.16 & 205.99 \\
\hline$(1,50)$ & 140.82 & 219.24 & 82.85 & 161.26 \\
\hline$(50,1)$ & 227.50 & 361.08 & 128.73 & 262.32 \\
\hline$(50,50)$ & 165.84 & 260.18 & 96.09 & 190.43 \\
\hline Region & \multicolumn{4}{|c|}{ Central Scotland } \\
\hline \multirow{2}{*}{$(\mathrm{PV}, \mathrm{EV}), \%$} & \multicolumn{4}{|c|}{ Tariff, $£$ (per household per year) } \\
\hline & (no EV, no PV) & $(\mathrm{EV}$, no PV) & (no EV, PV) & $(\mathrm{EV}, \mathrm{PV})$ \\
\hline$(1,1)$ & 122.42 & 172.93 & 65.15 & 115.67 \\
\hline$(1,50)$ & 102.25 & 143.39 & 55.60 & 96.74 \\
\hline$(50,1)$ & 160.27 & 228.35 & 83.08 & 151.16 \\
\hline$(50,50)$ & 125.09 & 176.84 & 66.41 & 118.16 \\
\hline Region & \multicolumn{4}{|c|}{ East Midlands } \\
\hline \multirow{2}{*}{$(\mathrm{PV}, \mathrm{EV}), \%$} & \multicolumn{4}{|c|}{ Tariff, $£$ (per household per year) } \\
\hline & (no EV, no PV) & $(E V$, no PV) & (no EV, PV) & $(\mathrm{EV}, \mathrm{PV})$ \\
\hline$(1,1)$ & 112.28 & 157.90 & 54.71 & 100.33 \\
\hline$(1,50)$ & 93.77 & 131.49 & 46.17 & 83.89 \\
\hline$(50,1)$ & 160.27 & 228.35 & 83.08 & 15116 \\
\hline$(50,50)$ & 117.80 & 165.78 & 57.26 & 105.24 \\
\hline
\end{tabular}

In addition, let us show the changes in the household demand profile with various levels of EV deployment stemming from the changes. Figure 5 that follows depicts some basic (rather "back-of-the-envelope") results of our calculations. Generally, it becomes apparent that with the rising share of EV in day-to-day transportation decisions, the demand profile can increase by $40 \%-50 \%$ during the peaks. All of these might cause serious issues for the energy systems that are not prepared for such scale of EV penetration.

Overall, there are two cases when EVs do not exhibit smart charging capability and when the EVs exhibit smart charging capability and are scheduled through dynamic pricing. In the former case, EVs are assumed to start charging immediately after returning home; given that most users return home during late afternoon and/or evening hours [17-21] when the non-EVs demand peak occurs, the system peak demand at these hours is significantly increased. In the latter case, the demand response of smart-charging EVs is concentrated and creates a new demand peak at the late-night hours of the day since the latter exhibit the lowest prices due to their low inflexible demand levels. 


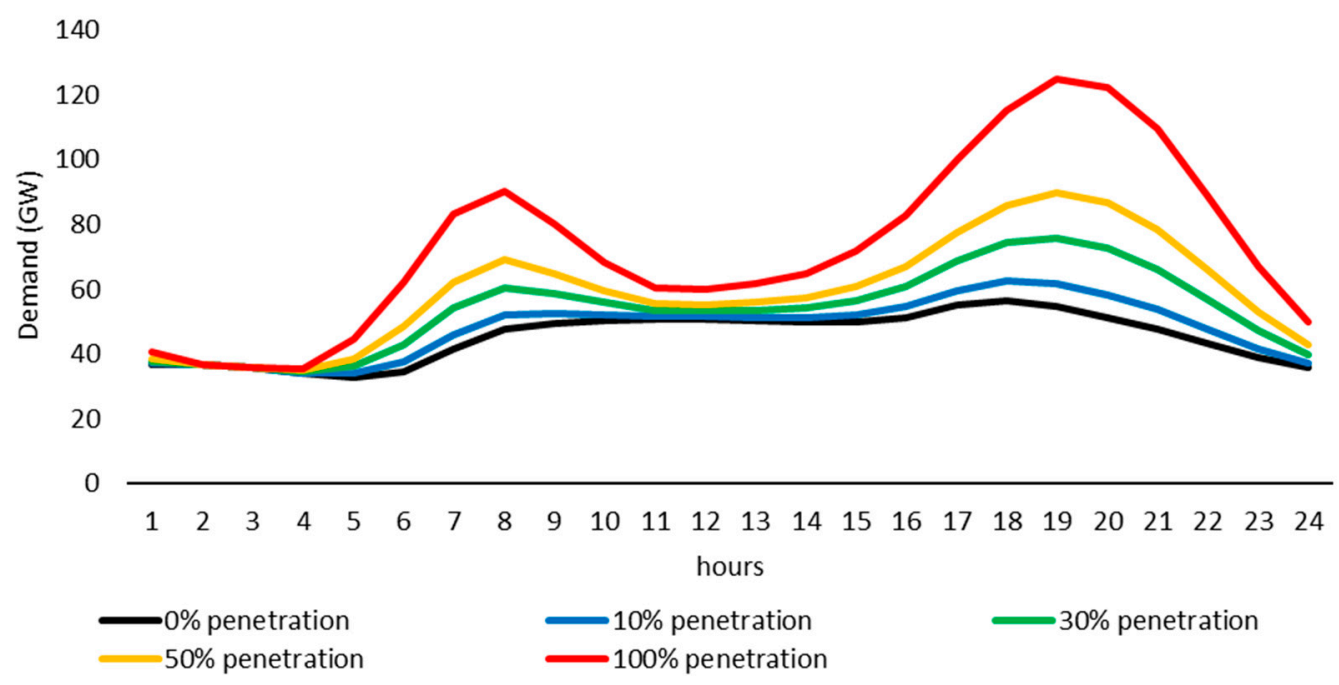

Figure 5. Household demand profile with various levels of EV deployment. Source: Own results.

\section{Conclusions and Implications}

The commitment to tackle global warming and climate change, with profound decarbonisation of the world's economies, is going to have many economic and social impacts and we all should be ready for them. Thence, political commitments that have an impact on the energy markets should also reflect the existing state of technological development and social acceptance of this development. This social acceptance is a serious issue because not all "traditional" energy providers and customers would be willing to change the old ways. Rapid flow of information and AI-like solutions that allow to optimize the flow of energy from producers to consumers and the flow of information the other way around (and vice versa) might be an issue for some individuals and companies. Some might even bring up an analogy to the "Big Brother" that is constantly monitoring each and every transaction and watching over each and every agent in the grid.

However, the trend might be also quite different as it happened with the ascent of Internet (which also served as an inspiration for the smart grids). Neglected and underestimated at first, the Internet quickly marched into our daily lives and fundamentally changed many principles of the world economy, quickly becoming a mundane issue for the majority of world's population. Its social acceptance is almost absolute, even though some people are starting to comprehend what threats it might cause. Similar things might happen to IoE and smart grids-once their potential is apparent and popularized, there will be no way back in reforming the current energy market design.

One would probably agree with the fact that the transition to the high-renewables electricity markets is going to be accompanied by the increasing share of RES in electricity generation. This will fundamentally alter the power markets within several decades and revert the existing rules that have been obeyed by energy market players for years. Renewable energy sources are gaining in importance with increasing power generation, and could easily cover half of the total energy demand by 2050 . The hope of accelerating the energy transition depends on the electrification of a larger part of the total energy consumption. Renewable energy advocates have received much good news over the past few years about falling solar and wind power prices and rapid growth rates in these industries.

With regard to the above, it is important for policymakers and stakeholders to understand the potential and the power of the ongoing "RES revolution" (which, one can argue, still represents an "evolution") and to prepare for the new market reality with all its outcomes and consequences. The profile of renewable energy development is becoming ever more diverse and in some regions of the world more and more challenges will have to be overcome. While global new investments in renewable energies are still relatively high, there has been some decline in recent years. 
In addition, it also appears that the deployment of different technologies and policy measures in the high-renewables energy system that would involve IoE would lead to the decentralized approach to system control and operation in the next few decades. Since it may be optimal that large-scale roll-out starts in the early 2020s if one is to reduce the cost of later investments, some government incentives may be needed for industry to make early moves.

Moreover, the concept of the "Internet of Energy" is very crucial for the demand flexibility (i.e., the case when demand for the electricity is steered to the grid off-peak periods using, for example, price incentives or reduced tariffs). Flexible energy revolution should be supported and implemented due to the growing demand and wide usage of electric vehicles (EV) and electric heating in the future. These technologies would help us to save carbon emissions, but they would be impossible to sustain without the major changes in the smart grid.

All in all, IoE and high-renewables electricity system market design represent a shift from asset redundancy to more intelligent operation through real-time coordination of new flexible technologies. With flexible demand, micro-generation, and energy storage technologies being able to reduce the emerging demand peaks, smart network technologies will increase the utilization of existing network assets, all representing a shift from asset redundancy to more intelligent operation through real-time coordination of new flexible technologies. Future demand and distributed generation connections are increasingly hard to predict due to uncertainty in timing, volume, and location of new demand, and connections of renewable generation due to their dependence on future technology developments, government policies, and market arrangements. Flexible planning frameworks are required to account for uncertainty in future development and identify investment strategies that are cost-efficient under all possible future realisations. Given all that above, we nevertheless have to stress that the outcomes of this paper mostly emerge from the energy policy aspects of high-renewables smart grids, and therefore does not attribute too much attention to the technical issues of Internet of Energy technique and the related framework applied to high renewables penetrations of electricity market.

Last but not least, high-renewables smart grids-focused electricity markets can increase economic efficiency and profits throughout the whole energy sector. While grid operators today hold natural monopolies, the shift to the high-renewables smart grids populated by millions and billions of prosumers might change the rules of the game and create the new revenue stream that would be beneficial for both energy suppliers (large and small) and energy consumers. Therefore, some forms of government funding are appropriate nowadays in order to boost this positive and highly desirable development towards the fundamental change of the existing energy system. This might include, for example, subsidies to the households and businesses for shifting towards electric transport, special preferential tariffs for renewable energy (feed-in-tariffs to buy out the "green" electricity), or special programs to increase environmental awareness, and the learning of how to increase energy efficiency by using advanced smart metering that would allow to constantly monitor the energy intake for each individual appliance and to assess it in a concise and comprehensive way (similar to the health data many of us assess using various fitness trackers and smart watches).

Supporting renewable energy demonstration projects to disseminate information in remote areas, training microfinance leaders, and decentralizing the implementation of renewable energy projects can promote the dissemination of renewable energy projects. Most of the support for renewable energy strategies and technologies in developing countries comes from local governments or from international donors, undermining their sustainability as funds vary with changing priorities and crises. Finally, the introduction of innovative strategies and the sustainability of renewable energy markets and technologies can benefit from the adoption of a comprehensive energy governance framework.

All in all, it appears that high-renewables electricity system market design would provide solutions to many issues including the $\mathrm{CO}_{2}$ reduction of mitigating environmental solution and climate change, however it needs more support from relevant stakeholders and policymakers aimed at securing its economic viability and helping to support its social acceptance and awareness. 
Author Contributions: Conceptualization, W.S., A.F., and E.S.; methodology, W.S. and D.S.; formal analysis, W.S., A.F., D.S., and E.S.; investigation, A.F., D.S., and E.S.; resources, A.F. and E.S.; data curation, W.S., A.F., and E.S.; writing—original draft preparation, W.S., D.S., A.F., and E.S.; writing-review and editing, W.S. and D.S.; visualization, W.S. and A.F.; supervision, W.S.; funding acquisition, A.F. and E.S. All authors have read and agreed to the published version of the manuscript.

Funding: This research received no external funding.

Conflicts of Interest: The authors declare no conflict of interest.

\section{References}

1. Newbery, D.; Pollitt, M.G.; Ritz, R.A.; Strielkowski, W. Market design for a high-renewables European electricity system. Renew. Sustain. Energy Rev. 2018, 91, 695-707. [CrossRef]

2. ILO, A. Design of the Smart Grid Architecture According to Fractal Principles and the Basics of Corresponding Market Structure. Energies 2019, 12, 4153. [CrossRef]

3. Ahmad, T.; Chen, H.; Wang, J.; Guo, Y. Review of various modeling techniques for the detection of electricity theft in smart grid environment. Renew. Sustain. Energy Rev. 2018, 82, 2916-2933. [CrossRef]

4. Strielkowski, W. Social and economic implications for the smart grids of the future. Econ. Sociol. 2017, 10, 310-318. [CrossRef]

5. Alahakoon, D.; Yu, X. Smart electricity meter data intelligence for future energy systems: A survey. IEEE Trans. Ind. Inform. 2015, 12, 425-436. [CrossRef]

6. Mengelkamp, E.; Gärttner, J.; Rock, K.; Kessler, S.; Orsini, L.; Weinhardt, C. Designing microgrid energy markets: A case study: The Brooklyn Microgrid. Appl. Energy 2018, 210, 870-880. [CrossRef]

7. Parag, Y.; Sovacool, B.K. Electricity market design for the prosumer era. Nat. Energy 2016, 1, 16032. [CrossRef]

8. Rana, M. Architecture of the Internet of energy network: An application to smart grid communications. IEEE Access 2017, 5, 4704-4710. [CrossRef]

9. Vrba, P.; Mařík, V.; Siano, P.; Leitão, P.; Zhabelova, G.; Vyatkin, V.; Strasser, T. A review of agent and service-oriented concepts applied to intelligent energy systems. IEEE Trans. Ind. Inform. 2014, 10, 1890-1903. [CrossRef]

10. Bui, N.; Castellani, A.P.; Casari, P.; Zorzi, M. The internet of energy: A web-enabled smart grid system. IEEE Netw. 2012, 26, 39-45. [CrossRef]

11. Wissner, M. The Smart Grid-a saucerful of secrets? Appl. Energy 2011, 88, 2509-2518. [CrossRef]

12. Dudin, M.N.; Frolova, E.E.; Protopopova, O.V.; Mamedov, A.A.; Odintsov, S.V. Study of innovative technologies in the energy industry: Nontraditional and renewable energy sources. Entrep. Sustain. Issues 2019, 6, 1704-1713. [CrossRef]

13. Pavić, I.; Capuder, T.; Kuzle, I. Low carbon technologies as providers of operational flexibility in future power systems. Appl. Energy 2016, 168, 724-738. [CrossRef]

14. Kabalci, Y. A survey on smart metering and smart grid communication. Renew. Sustain. Energy Rev. 2016, 57, 302-318. [CrossRef]

15. Palensky, P.; Kupzog, F. Smart grids. Annu. Rev. Environ. Resour. 2013, 38, 201-226. [CrossRef]

16. de Tena, D.L.; Pregger, T. Impact of electric vehicles on a future renewable energy-based power system in Europe with a focus on Germany. Int. J. Energy Res. 2018, 42, 2670-2685. [CrossRef]

17. Nyberg, R.A. Using 'smartness' to reorganise sectors: Energy infrastructure and information engagement. Int. J. Inf. Manag. 2018, 39, 60-68. [CrossRef]

18. Vlasov, A.I.; Shakhnov, V.A.; Filin, S.S.; Krivoshein, A.I. Sustainable energy systems in the digital economy: Concept of smart machines. Entrep. Sustain. Issues 2019, 6, 1975-1986. [CrossRef]

19. Akhavan-Hejazi, H.; Mohsenian-Rad, H. Power systems big data analytics: An assessment of paradigm shift barriers and prospects. Energy Rep. 2018, 4, 91-100. [CrossRef]

20. Koirala, B.P.; Koliou, E.; Friege, J.; Hakvoort, R.A.; Herder, P.M. Energetic communities for community energy: A review of key issues and trends shaping integrated community energy systems. Renew. Sustain. Energy Rev. 2016, 56, 722-744. [CrossRef]

21. Osório, G.J.; Shafie-khah, M.; Carvalho, G.C.; Catalão, J.P. Analysis Application of Controllable Load Appliances Management in a Smart Home. Energies 2019, 12, 3710. [CrossRef] 
22. Kakran, S.; Chanana, S. Smart operations of smart grids integrated with distributed generation: A review. Renew. Sustain. Energy Rev. 2018, 81, 524-535. [CrossRef]

23. Salmerón-Manzano, E.; Manzano-Agugliaro, F. The Role of Smart Contracts in Sustainability: Worldwide Research Trends. Sustainability 2019, 11, 3049. [CrossRef]

24. Li, Y.; Cheng, X.; Cao, Y.; Wang, D.; Yang, L. Smart Choice for the Smart Grid: Narrowband Internet of Things (NB-IoT). IEEE Internet Things J. 2018, 5, 1505-1515. [CrossRef]

25. Valtanen, K.; Backman, J.; Yrjölä, S. Blockchain-Powered Value Creation in the 5G and Smart Grid Use Cases. IEEE Access 2019, 7, 25690-25707. [CrossRef]

26. Kuzmin, E.A.; Volkova, E.E.; Fomina, A.V. Research on the concentration of companies in the electric power market of Russia. Int. J. Energy Econ. Policy 2019, 9, 130-136. [CrossRef]

27. Ma, R.; Chen, H.H.; Huang, Y.R.; Meng, W. Smart grid communication: Its challenges and opportunities. IEEE Trans. Smart Grid 2013, 4, 36-46. [CrossRef]

28. Huang, B.; Li, Y.; Zhang, H.; Sun, Q. Distributed optimal co-multi-microgrids energy management for energy internet. IEEE CAA J. Autom. Sin. 2016, 3, 357-364. [CrossRef]

29. Pina, A.; Silva, C.; Ferrão, P. The impact of demand side management strategies in the penetration of renewable electricity. Energy 2012, 41, 128-137. [CrossRef]

30. Strielkowski, W.; Štreimikienè, D.; Bilan, Y. Network charging and residential tariffs: A case of household photovoltaics in the United Kingdom. Renew. Sustain. Energy Rev. 2017, 77, 461-473. [CrossRef]

31. McArthur, S.; Taylor, P.; Ault, G.W.; King, J.; Athanasiadis, D.; Alimisis, V.; Czaplewski, M. The autonomic power system-network operation and control beyond smart grids. In Proceedings of the 3rd IEEE PES Innovative Smart Grid Technologies (ISGT Europe), Berlin, Germany, 14-17 October 2012; pp. 1-7. [CrossRef]

32. Papadaskalopoulos, D.; Strbac, G. Nonlinear and Randomized Pricing for Distributed Management of Flexible Loads. IEEE Trans. Smart Grid 2016, 7, 1137-1146. [CrossRef]

33. Xu, Y.; Milanovic, J.V. Artificial-Intelligence-Based Methodology for Load Disaggregation at Bulk Supply Point. IEEE Trans. Power Syst. 2015, 30, 795-803. [CrossRef]

34. Reka, S.S.; Dragicevic, T. Future effectual role of energy delivery: A comprehensive review of Internet of Things and smart grid. Renew. Sustain. Energy Rev. 2018, 91, 90-108. [CrossRef]

35. Hwang, L.C.; Chen, C.S.; Ku, T.T.; Shyu, W.C. A bridge between the smart grid and the Internet of Things: Theoretical and practical roles of LoRa. Int. J. Electr. Power Energy Syst. 2019, 113, 971-981. [CrossRef]

36. Holttinen, H.; Meibom, P.; Orths, A.; Lange, B.; O’Malley, M.; Tande, J.O.; Smith, J.C. Impacts of large amounts of wind power on design and operation of power systems, results of IEA collaboration. Wind Energy 2011, 14, 179-192. [CrossRef]

37. Connor, P.M.; Baker, P.E.; Xenias, D.; Balta-Ozkan, N.; Axon, C.J.; Cipcigan, L. Policy and regulation for smart grids in the United Kingdom. Renew. Sustain. Energy Rev. 2014, 40, 269-286. [CrossRef]

38. Jenkins, J.D.; Pérez-Arriaga, I.J. Improved regulatory approaches for the remuneration of electricity distribution utilities with high penetrations of distributed energy resources. Energy J. 2017, 38, 63-91. [CrossRef]

39. Lo, C.H.; Ansari, N. The progressive smart grid system from both power and communications aspects. IEEE Commun. Surv. Tutor. 2011, 14, 799-821. [CrossRef]

40. Defeuilley, C. Energy transition and the future (s) of the electricity sector. Util. Policy 2019, 57, 97-105. [CrossRef]

41. Mitchell, C. Momentum is increasing towards a flexible electricity system based on renewables. Nat. Energy 2016, 1, 15030. [CrossRef]

42. Rausser, G.; Strielkowski, W.; Štreimikienè, D. Smart meters and household electricity consumption: A case study in Ireland. Energy Environ. 2018, 29, 131-146. [CrossRef]

43. Reddy, K.S.; Kumar, M.; Mallick, T.K.; Sharon, H.; Lokeswaran, S. A review of Integration, Control, Communication and Metering (ICCM) of renewable energy based smart grid. Renew. Sustain. Energy Rev. 2014, 38, 180-192. [CrossRef]

44. Byun, J.; Hong, I.; Park, S. Intelligent cloud home energy management system using household appliance priority based scheduling based on prediction of renewable energy capability. IEEE Trans. Consum. Electron. 2012, 58, 1194-1201. [CrossRef]

45. Gelazanskas, L.; Gamage, K.A. Demand side management in smart grid: A review and proposals for future direction. Sustain. Cities Soc. 2014, 11, 22-30. [CrossRef]

46. Daki, H.; El Hannani, A.; Aqqal, A.; Haidine, A.; Dahbi, A. Big Data management in smart grid: Concepts, requirements and implementation. J. Big Data 2017, 4, 1-19. [CrossRef] 
47. Zanella, A.; Bui, N.; Castellani, A.; Vangelista, L.; Zorzi, M. Internet of Things for Smart Cities. IEEE Internet Things J. 2014, 1, 22-32. [CrossRef]

48. Cerruela García, G.; Luque Ruiz, I.; Gómez-Nieto, M.Á. State of the art, trends and future of bluetooth low energy, near field communication and visible light communication in the development of smart cities. Sensors 2016, 16, 1968. [CrossRef]

49. Jaradat, M.; Jarrah, M.; Bousselham, A.; Jararweh, Y.; Al-Ayyoub, M. The internet of energy: Smart sensor networks and big data management for smart grid. Procedia Comput. Sci. 2015, 56, 592-597. [CrossRef]

50. Kaygusuz, K. Energy situation, future developments, energy saving, and energy efficiency in Turkey. Energy Sources 1999, 21, 405-416. [CrossRef]

51. Uddin, M.; Rahman, A.A. Energy efficiency and low carbon enabler green IT framework for data centers considering green metrics. Renew. Sustain. Energy Rev. 2012, 16, 4078-4094. [CrossRef]

52. Çengel, Y.A. Energy efficiency as an inexhaustible energy resource with perspectives from the US and Turkey. Int. J. Energy Res. 2011, 35, 153-161. [CrossRef]

53. Brook, B.; Blees, T.; Wigley, T.; Hong, S. Silver Buckshot or Bullet: Is a Future "Energy Mix" Necessary? Sustainability 2018, 10, 302. [CrossRef]

54. Davis, S.J.; Lewis, N.S.; Shaner, M.; Aggarwal, S.; Arent, D.; Azevedo, I.L.; Benson, S.M.; Bradley, T.; Brouwer, J.; Chiang, Y.M.; et al. Net-zero emissions energy systems. Science 2018, 360. [CrossRef] [PubMed]

55. Deng, X.; Lv, T. Power system planning with increasing variable renewable energy: A review of optimization models. J. Clean. Prod. 2019. [CrossRef]

56. Zöphel, C.; Schreiber, S.; Müller, T.; Möst, D. Which Flexibility Options Facilitate the Integration of Intermittent Renewable Energy Sources in Electricity Systems? Curr. Sustain. Renew. Energy Rep. 2018, 5, 37-44. [CrossRef]

57. Yixian, L.I.U.; Roberts, M.C.; Sioshansi, R. A vector autoregression weather model for electricity supply and demand modeling. J. Modern Power Syst. Clean Energy 2018, 6, 763-776. [CrossRef]

58. Horst, D.; Jentsch, M.; Pfennig, M.; Mitra, I.; Bofinger, S. Impact of renewable energies on the indian power system: Energy meteorological influences and case study of eefects on existing power fleet for rajasthan state. Energy Policy 2018, 122, 486-498. [CrossRef]

59. Jerez, S.; Tobin, I.; Turco, M.; Jiménez-Guerrero, P.; Vautard, R.; Montávez, J.P. Future changes, or lack thereof, in the temporal variability of the combined wind-plus-solar power production in Europe. Renew. Energy 2019, 139, 251-260. [CrossRef]

60. Johansson, P.O.; Kriström, B. Welfare evaluation of subsidies to renewable energy in general equilibrium: Theory and application. Energy Econ. 2019, 83, 144-155. [CrossRef]

61. Simshauser, P. On the Stability of Energy-Only Markets with Government-Initiated Contracts-for-Differences. Energies 2019, 12, 2566. [CrossRef]

62. Ringkjøb, H.K.; Haugan, P.M.; Solbrekke, I.M. A review of modelling tools for energy and electricity systems with large shares of variable renewables. Renew. Sustain. Energy Rev. 2018, 96, 440-459. [CrossRef]

63. Ma, S.; Geng, H.; Yang, G.; Pal, B.C. Clustering-Based Coordinated Control of Large-Scale Wind Farm for Power System Frequency Support. IEEE Trans. Sustain. Energy 2018, 9, 1555-1564. [CrossRef]

64. Zeng, Y.; Zhang, R.; Wang, D.; Mu, Y.; Jia, H. A regional power grid operation and planning method considering renewable energy generation and load control. Appl. Energy 2019, 237, 304-313. [CrossRef]

65. Szabó, L.; Kelemen, Á.; Mezősi, A.; Pató, Z.; Kácsor, E.; Resch, G.; Liebmann, L. South East Europe electricity roadmap-modelling energy transition in the electricity sectors. Clim. Policy 2019, 19, 495-510. [CrossRef]

66. Kraan, O.; Kramer, G.J.; Nikolic, I.; Chappin, E.; Koning, V. Why fully liberalised electricity markets will fail to meet deep decarbonisation targets even with strong carbon pricing. Energy Policy 2019, 131, 99-110. [CrossRef]

67. Godoy-González, D.; Gil, E.; Gutiérrez-Alcaraz, G. Ramping ancillary service for cost-based electricity markets with high penetration of variable renewable energy. Energy Econ. 2019, 85, 104556. [CrossRef]

68. Sinsel, S.R.; Yan, X.; Stephan, A. Building resilient renewable power generation portfolios: The impact of diversification on investors' risk and return. Appl. Energy 2019, 254, 113348. [CrossRef]

69. Miller, L.; Carriveau, R. Energy demand curve variables-An overview of individual and systemic effects. Sustain. Energy Technol. Assess. 2019, 35, 172-179. [CrossRef]

70. Brown, M.A.; Zhou, S.; Ahmadi, M. Smart grid governance: An international review of evolving policy issues and innovations. Wiley Interdiscip. Rev. Energy Environ. 2018, 7, e290. [CrossRef] 
71. Sakti, A.; Botterud, A.; O'Sullivan, F. Review of wholesale markets and regulations for advanced energy storage services in the United States: Current status and path forward. Energy Policy 2018, 120, 569-579. [CrossRef]

72. EIA. Annual Energy Outlook 2018. 2019. Available online: https://www.eia.gov/outlooks/aeo/pdf/electricity_ generation.pdf (accessed on 18 October 2019).

73. IEA. Smart Grids. 2019. Available online: https://www.iea.org/tcep/energyintegration/smartgrids (accessed on 18 October 2019).

74. Strbac, G.; Konstantelos, I.; Aunedi, M.; Pollitt, M.; Green, R. Delivering Future-Proof Energy Infrastructure. Report for National Infrastructure Commission. 2016. Available online: https://www.gov.uk/government/uploads/system/uploads/attachment_data/file/507256/Future-proof_ energy_infrastructure_Imp_Cam_Feb_2016.pdf (accessed on 7 October 2019).

75. Shivakumar, A.; Pye, S.; Anjo, J.; Miller, M.; Rouelle, P.B.; Densing, M.; Kober, T. Smart energy solutions in the EU: State of play and measuring progress. Energy Strategy Rev. 2018, 20, 133-149. [CrossRef]

76. Strbac, G.; Pollitt, M.; Konstantinidis, C.V.; Konstantelos, I.; Moreno, R.; Newbery, D.; Green, R. Electricity transmission arrangements in Great Britain: Time for change? Energy Policy 2014, 73, 298-311. [CrossRef]

77. Popovič, A.; Hackney, R.; Tassabehji, R.; Castelli, M. The impact of big data analytics on firms' high value business performance. Inf. Syst. Front. 2018, 20, 209-222. [CrossRef]

78. Minchala-Avila, L.I.; Garza-Castañón, L.E.; Vargas-Martínez, A.; Zhang, Y. A Review of Optimal Control Techniques Applied to the Energy Management and Control of Microgrids. Procedia Comput. Sci. 2015, 52, 780-787. [CrossRef]

79. Hakimi, S.M.; Hasankhani, A.; Shafie-khah, M.; Catalão, J.P.S. Optimal sizing and siting of smart microgrid components under high renewables penetration considering demand response. IET Renew. Power Gener. 2019, 13, 1809-1822. [CrossRef]

80. Yang, C.; Yao, J.; Lou, W.; Xie, S. On Demand Response Management Performance Optimization for Microgrids Under Imperfect Communication Constraints. IEEE Internet Things J. 2017, 4, 881-893. [CrossRef]

81. Strbac, G. Demand side management: Benefits and challenges. Energy Policy 2008, 36, 4419-4426. [CrossRef]

82. Electrive. Number of Plug-In Cars Climbs to 5.6M Worldwide. 2019. Available online: https://www.electrive. com/2019/02/11/the-number-of-evs-climbs-to-5-6-million-worldwide (accessed on 29 November 2019).

83. Statista. Worldwide Number of Battery Electric Vehicles in Use From 2012 to 2018. 2019. Available online: https:/www.statista.com/statistics/270603/worldwide-number-of-hybrid-and-electric-vehicles-since2009 (accessed on 28 November 2019).

84. Carsguide. How Many Cars Are There in the World? 2019. Available online: https://www.carsguide.com.au/ car-advice/how-many-cars-are-there-in-the-world-70629 (accessed on 28 November 2019).

85. HIS Markit. Number of Fast-Charging Stations for Electric Vehicles set to Rise to Nearly 200,000 in 2020. 2019. Available online: https://news.ihsmarkit.com/press-release/design-supply-chain-media/number-fastcharging-stations-electric-vehicles-set-rise-nea?page=1 (accessed on 29 November 2019).

86. Statista. Number of Fast-Charging Stations for Electric Vehicles Worldwide in 2013 and 2020. 2019. Available online: https://www.statista.com/statistics/283531/electric-vehicles--global-number-offast-charging-stations/ (accessed on 29 November 2019).

87. Strielkowski, W.; Volkova, E.; Pushkareva, L.; Streimikiene, D. Innovative Policies for Energy Efficiency and the Use of Renewables in Households. Energies 2019, 12, 1392. [CrossRef]

88. Taiebat, M.; Xu, M. Synergies of four emerging technologies for accelerated adoption of electric vehicles: Shared mobility, wireless charging, vehicle-to-grid, and vehicle automation. J. Clean. Prod. 2019, 230, 794-797. [CrossRef]

89. Newbery, D.; Strbac, G. What is needed for battery electric vehicles to become socially cost competitive? Econ. Transp. 2016, 5, 1-11. [CrossRef]

90. Parsons, G.R.; Hidrue, M.K.; Kempton, W.; Gardner, M.P. Willingness to pay for vehicle-to-grid (V2G) electric vehicles and their contract terms. Energy Econ. 2014, 42, 313-324. [CrossRef]

(C) 2019 by the authors. Licensee MDPI, Basel, Switzerland. This article is an open access article distributed under the terms and conditions of the Creative Commons Attribution (CC BY) license (http://creativecommons.org/licenses/by/4.0/). 